\title{
OgUAA JOURNAL OF SOCIAL SCIENCES
}

VOLUME 9 ISSUE 1, JUNE 2020 


\title{
INFORMAL OPERATORS IN WASTE MANAGEMENT IN ACCRA, GHANA: FROM NEGLECT TO RECOGNITION?
}

\author{
Owusu Boampong ${ }^{1}$, Akua O. Britwum ${ }^{2}$ and Angela D. Akorsu ${ }^{2}$ \\ ${ }^{1}$ Department of Integrated Development Studies, School for Development Studies, University of Cape Coast, \\ Ghana \\ ${ }^{2}$ Department of Labour and Human Resource Studies, School for Development Studies, University of Cape \\ Coast, Ghana
}

\begin{abstract}
Informal waste collectors play an essential role in urban solid waste management; however, in many developing countries, they are neglected in the waste management policy framework. This paper explored the policy regime of informal waste operators in waste management in Accra, Ghana. Drawing on qualitative data from in-depth interviews and focus group discussions with informal waste collectors, private waste companies and officials of Accra Metropolitan Assembly, the paper shows that formal waste contractors with concession rights underserve low-class areas due to operational difficulties. The informal waste collectors fill this gap by providing services to these underserved communities though they have no legal entitlement to the concessions. The formal waste contractors
\end{abstract}

\section{Introduction}

Once a public service, municipal waste management is increasingly being undertaken by private contractors who are assuming prominent role in the collection and disposal of municipal solid waste within the framework of publicprivate partnership (Van de Klundert Lardinois, 1995; Contreau-Levine, 1995; Oteng-Ababio, 2010; Kassim and Ali, 2006; Katusiimeh, Mol and Burger, 2012). In the process, informal workers who are critical stakeholders in municipal waste management have either been neglected or repressed by government officials who accuse them of engaging in illegal activities and of being a nuisance to city management in many developing countries (Wilson, Velis and Cheeseman, 2006). Studies, however, indicate a gradual shift in attitude towards recognition of informal waste workers as important actors in municipal waste management (Medina, 1997; Wilson et al., 2006; Baudouin, Bjerkli, Habtemaraim, and Chekole, 2010).

In sub-Saharan Africa and in particular cities in West Africa, studies conducted in the 1990s highlighted the regime of governments' and the municipal authorities recognize this gapfilling role of informal waste collectors in waste management in Accra yet fail to provide the official recognition to legitimise their participation in solid waste management. The lack of official recognition, even in formal policy documents, undermines the development of informal waste management services as a viable employment option. It also denies a substantial section of the residents in poorer neighbourhoods in the national capital access to affordable and efficient waste management services.

Keywords: Accra, policy, informal waste collectors, formal waste contractors

ambivalence or neglect towards the role of informal waste collectors in municipal waste management (Waas and Diop, 1990; Diallo and Coulibly, 1990; Tonon, 1990, as cited in Medina, 1997). Adama and Nzeadibe (2013, p.1) have noted that the participation of informal waste operators in the waste management process in Nigeria is constrained by the "lack of an articulate and inclusive policy on solid waste management ... and the informal [economy] is not recognised in waste management policy, planning and practice". Similarly, Oteng-Ababio (2010, p.322) has observed that the Government of Ghana often considers public-private partnership “...only in terms of 'formal sector' companies but fail to recognise the role played by informal operators." This paper seeks to contribute to the discourse on the policy environment of informal operators engaged in municipal waste management, especially within the context of the privatisation of waste management services in Accra. What policy regulates the operations of the informal waste collectors? And what enabling conditions are emerging for possible formal integration of informal waste collectors? 
Empirical studies in cities in Latin America and Asia suggest that informal waste collectors have been engaging municipal authorities and other actors to create a favourable regulatory space through the agency of their self-organized associations, non-governmental organisations (NGOs) and sometimes trade unions (Medina, 1997; Wilson et al., 2006; Samson, 2009; Baudouin et al., 2010). Since informal waste workers in most cases are denied access to the source of waste generation, Gupta (2012) argues that the effort to give official recognition to informal waste collectors should begin with granting them the right of access to waste. In the view of Gupta, to achieve this requires informal waste collectors' engagement with municipal authorities (through their self-organised associations and NGOs) to grant them the right of access to waste, which is at the very foundation of their livelihoods. To reinforce this view, Gadgil and Sampson (2017, p.162) observe that the signing of an official agreement between the Solid Waste Collection and Handling ( $\mathrm{SWaCH}$ ) cooperative in Pune, India and the municipal authority as the sole provider of door-to-door collection services provided the waste pickers with secure access to materials.

Based on case studies from India, Brazil, and Egypt, Gerdes and Gunsilius (2010) tease out the enabling factors for creating formal policy space for informal waste collectors. These include what they call voice, visibility, validity, and viability (the $4 \mathrm{Vs}$ ). Voice is about the organisation of informal waste collectors into a membership-based association that is accountable to its members and represents the interest of members in relevant policy-making institutions. When local and national government officials recognise the contribution of informal waste collectors - in the areas of economic, social, and the environment - and substantiated through robust policy research, it gives them visibility. The activities of informal waste collectors are offered validity when there is the political will on the part of local and national governments to grant informal waste collectors and their associations the legal right to operate. The commercial viability of informal waste enterprises are considered an essential prerequisite for any attempt at formalising the sector. In this regard, the economic analysis of informal waste operators should signal their ability to compete under prevailing market conditions.

In the context of privatised solid waste management services, the probable alternative path for integrating informal operators into the waste management system is either a direct contract with municipal authorities or formal waste companies. But sometimes, the relationship between the informal operators and the formal contractors may be conflictual. This situation arises when informal waste operators become competitors of formal waste management service providers (Gupta, 2012; Gerdes and Gunsilius 2010). Nonetheless, Gerdes and Gunsilius (2010) note that identifying points for common interests could be an essential step toward collaboration between informal operators and formal waste companies, and this ultimately benefits informal operators. As they put it: "seeking convergent interests/complementary action between formal sector enterprises and the informal sector can strengthen the position of the informal sector [operators]" (p.25).

According to Oteng-Ababio (2010), between 60 to 80 percent of residents he interviewed in middle-income areas of Accra patronise the services of informal waste pickers (Kaya Borla). Various reasons account for the involvement of informal waste pickers in SWM agenda in Ghana not least because of the irregularity of service delivery by the public sector. The "inefficiencies in the public sector whose services can be characterised as irregular, skewed and inefficient... [compel] the public to seek alternative waste disposal system, hence the relevance of the informal sector" (OtengAbabio, 2011a: 416). This paper reinforces this observation and indicates that within the context of privatised waste management services in Accra; the formal waste contractors who are the primary stakeholders have shown weaknesses in accessing low-income areas. The informal waste collectors have responded to this weakness by providing services to these areas even though they do not have the legal right to operate. Characteristically, the casual waste operators have shown that they are entrepreneurs capable of spotting opportunity in the inefficiencies of formal actors (both public and private) in the waste sector and turning these to their advantage. The economic and environmental importance of informal waste operators has received considerable attention in the literature (Gupta, 2012; Gerdes and Gunsilius, 2010; Wilson et al., 2006). Oteng-Ababio (2011a), in his study on the role of informal waste operators in Accra, highlights the employment and environmental benefits of casual operators in waste management. Several migrant youths work in this sector, and indeed, the incomes of some informal waste collectors are higher than that of most public sector workers. Again, through 
their ability to offer waste management services to low-income areas, which are inaccessible to formal service providers due to infrastructural constraints, the informal waste collectors help to cultivate a healthy environment in the city by their penetration into such spaces. Within the context of West Africa, the literature is, however, scant on the changing attitudes of local authorities towards informal waste workers and the emerging enabling factors that can ensure the integration of casual waste workers into the waste management system. This is the gap the study sought to address.

After this introductory section, the next section reviews the existing literature on the policy environment of informal operators in developing countries. The rest of the paper is structured into the following themes; the place of informal operators in Ghana's SWM policy, the agency of informal waste operators to create policy space for themselves, the enabling role of some stakeholders in negotiating for the rights of informal operators within the Accra Metropolis and the conclusion.

\section{Public Policies for informal collectors in waste management}

The literature highlights varying official attitudes of state actors to informal workers in waste management (Medina, 1997; Scheinberg, 2001; Wilson et al. 2006; Samson, 2009; Baudouin et al., 2010). Official attitudes have been identified as either negative or supportive and each position is associated with different policy levels (see Table 1). Some researchers show that existing relationships between city authorities and informal waste workers in many developing countries range from neglect, repression, collusion, recognition, partnership and integration (Medina, 1997; Scheinberg, 2001; Wilson et al., 2006; Samson, 2009; Baudouin et al., 2010; Oteng-Ababio, 2010). Repressive policy manifests in the form of restrictive and hostile attitudes of government and city officials toward informal waste workers (Table 1). Under such a system, the informal waste workers are stigmatized, their activities are often viewed as illegal, a nuisance and punishable in many developing countries. This restrictive policy is noted to be prevalent in countries such as Columbia, India, and the Philippines (Medina, 1997). Neglect becomes manifest when government authorities are indifferent toward informal waste operators' activities; the casual waste workers are neither persecuted nor offered assistance by government officials. The policy of neglect is typified by cities in West Africa (Wilson et al., 2006; Medina, 1997). Collusion is characterized by government officials developing with informal waste workers a relationship of political clientelism whereby government officials collect bribes and seek political support from casual waste workers and the casual waste workers, in turn, obtain some legitimacy and stability in their operations. According to Medina (1997), Mexico exemplifies the policy of collusion between informal waste workers and city authorities.

The three policy levels (repression, neglect, and collusion) represent a negative relationship between state actors and informal waste workers. However, there appears to be a gradual shift in the attitude of government officials in developing countries who now view the informal waste sector as a resource that must be harnessed (Wilson et al., 2006). They are consequently turning to be supportive of the industry. According to Medina (1997, p.16), "Recognising the economic, social and environmental benefits of informal waste workers, governments have begun to change their previous attitudes of opposition, indifference or intolerance, to one of active support". The loving environment of the informal waste workers begins with a change in negative attitudes of government officials toward the sector (Table 1). The supportive posture of governments has variously been termed as recognition (Scheinberg, 2001), stimulation (Medina, 1997), partnership and integration (Wilson et al., 2006; Baudouin et al., 2010).

Scheinberg (2001) uses a three-step approach to describe a supportive and positive engagement between governments and informal waste operators in developing countries. The first step is where city officials acknowledge the existence of informal workers and take inventory of their activities. The second step is recognition and legitimization, which emphasizes partnership between local authorities and groups of informal waste workers through a franchise, concession, or even a contract for the services they are performing. This description is consistent with Medina's (1997) concept of stimulation, which is defined as an on-going partnership (Baudouin et al., 2010). Concerning stimulation, the government or a non-governmental organisation encourages the formation of informal waste workers cooperatives and provides them with financial assistance to acquire waste collection equipment and infrastructure and other forms of support from municipal authorities. In other words, the creation of a supportive policy environment for informal waste collectors does not happen in a vacuum. It is 
Table 1: Public Policy Orientation for Informal collectors in Waste Management

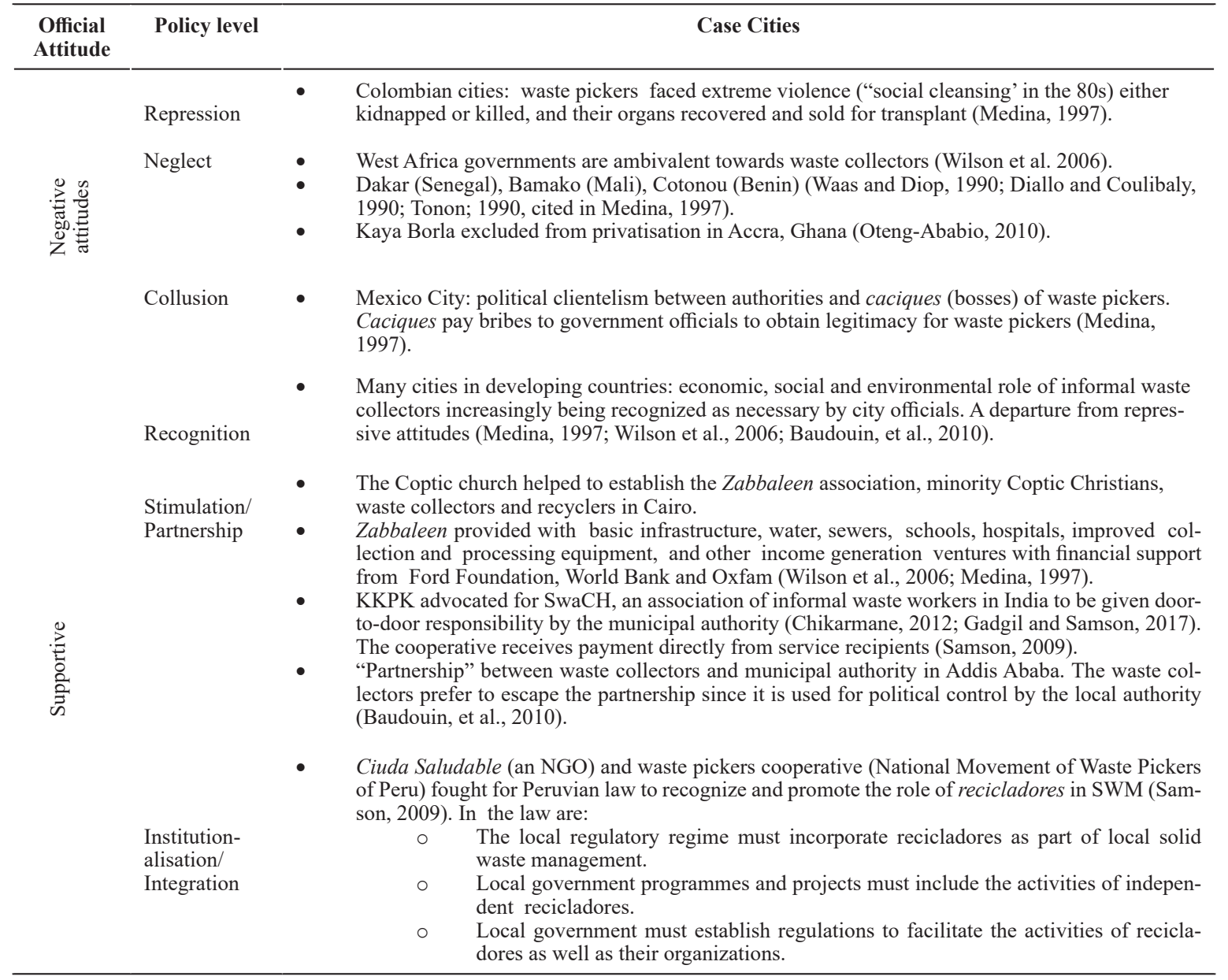

Source: Authors' construct derived from the review of the existing literature

preferably achieved through the agency of informalbased associations, NGOs and Trade Unions (such as Kagad Kach Patra Kashtakari Panchayat of India that helped to form $\mathrm{SwaCH}$, the association of waste pickers) often working as a collective to seek official recognition and support for informal waste collectors. In Cairo, for example, the Coptic Church helped to establish the Zabbaleen association (waste collectors and recyclers). The association was provided with necessary infrastructure, water, sewers, schools, hospitals, improved collection, and processing equipment, and other income generation ventures with financial support from the Egyptian government and other donor agencies (Wilson et al., 2006; Medina, 1997). The distinction between stimulation and Scheinberg's notion of recognition and legitimization is a bit blurred since both concepts stress a sort of acceptance of the role of, and support for, informal waste collectors by government. Another path of seeking the integration of informal waste operators into the broader solid waste management is either through a partnership with municipal authority or direct contractual relationship with formal private contractors (Gupta, 2012; Gerdes and Gunsilius 2010). Local authorities in SubSaharan Africa are increasingly encouraging publicprivate partnership in solid waste management in cities such as Accra, (Ghana), Kampala, (Uganda) and Dar es Salaam, (Tanzania) (Oteng-Ababio, 2010; Kassim and Ali, 2006; Katusiimeh et al., 2012). The partnership, in most cases, is between formal private contractors and local authorities to the neglect of informal waste collectors (Oteng-Ababio, 2010). The instances of an empirical partnership between municipal authorities and informal waste collectors are rare (Baudouin et al., 2010). The few cases of a collaboration between groups of casual waste operators and municipal authorities are dotted in the relatively advanced developing countries such as Brazil, India, and Egypt (see case studies in Gerdes and Gunsilius 2010). The exception in Sub-Saharan Africa (SSA) is the arrangement between the municipal authority and informal waste collectors in Ethiopia (Baudouin et al., 2010). The authors, however, noted that the city officials in Addis Ababa used the partnership as a political tool to control informal waste workers, which negatively affected the success of the partnership. 
The policy by the municipal authorities to supplant existing informal waste collectors with "newly created" partisan informal waste groups led to severe conflicts between the existing informal waste collectors and the authorities. As a result, the "informal actors, far from seeking recognition, prefer to 'escape' [from the partnership] by refusing any contact with the municipality" (Baudouin, et al., 2010, p.30). The waste collectors were eager to disengage from the partnership since it was used by the local authority for political control and patronage. The third level outlined by Scheinberg (2001) is the institutionalization of informal waste collectors as part of the broader municipal waste management system. It is the purposeful attempt by the government to integrate the activities of informal waste collectors into an overall waste management regulation and policy. This is an arduous task which few developing countries have been able to achieve.

\section{Methodology}

The paper draws on data collected through interviews and focus group discussions with key actors in the waste management sector in Accra from August to September 2014. The study participants were purposively selected from different categories of respondents. These respondents have had working experience in the waste management sector and therefore, their selection for interviews was deemed an appropriate source of data for the study. These included the respondents from solid waste workers and leaders of informal waste workers' groups. Their views were augmented with that of key informants from officials of private waste contractors' association and AMA. A total of 22 individual interviews and 3 Focus Group Discussions (FGDs) were conducted. The instruments for data collection were interview guides and FGD guide that sought the perspectives of respondents on a wide range of issues including the policy environment of waste collection and the relationship between informal waste collectors and the city authorities. The data captured on audiotapes were transcribed and manually processed for the analysis.

The conceptual framework (Table 1) informs the analyses of the empirical data in line with the objective of the paper; the exploration of the policy regime of informal waste collectors engaged in waste management in Accra. Specifically, we looked at the attitudes of officials (negative or supportive) toward informal waste operators, the policy level (regression, neglect, collusion, recognition, stimulation and integration) and the expression of agency either through the effort of the informal operators themselves or other stakeholders to create favourable policy space for their operations.

\section{Informal Waste Collectors in Accra}

The informal waste collectors in Accra are categorised into service-based and commoditybased collectors. The more visible service-based casual waste collectors in Accra are the Kaya Borla and the Taxi Borla. Kaya Borla are porters who use baskets, sacks, and pushcarts to collect household and commercial waste to dumping sites for a fee. Additionally, they may recover valuable materials and sell them for additional income. The Taxi Borla operators provide direct waste collection services to clients, traders, or households, for a fee and mostly use motorised tricycles in their operations. They are recent players in the sector who have carved a niche for themselves in the low income and slum areas in Accra such as Nima, Chorkor, Sukura, and Agbogbloshie by offering house to house waste collection and disposal services where formal waste contractors have operational challenges (see Figure 1).

The informal commodity-based waste collectors identifiable in Accra are dumpsite waste pickers, the scrap boys/van dealers, scrap masters, junior 'totse' and senior 'totse.' They sort and collect plastics at dumpsites and sell to itinerant waste buyers. The scrap boys and van dealers are predominantly male itinerant scrap metal purchasers who buy waste metal from households and mechanic shops, waste pickers and local waste crews and stationary metal collectors in satellite locations. The scrap boys usually work in pairs and often use 4-wheel push trucks to cart metal waste from the generation point to the metal yards. The scrap masters are middle-aged persons operating in the scrap metal yard. They provide daily capital to their contract partners to purchase recovered metal waste. They own open spaces or sheds at Agbogbloshie yard where they extract and store metals. Totse (Itinerant glass and plastic waste buyers) means "father of bottles." They roam the neighbourhoods, from household to household, collecting plastics and glass they find or buying them from pickers for resale in the domestic and export markets (e.g., China). There are junior totse and senior totse. The junior totse, like scrap boys, are contract partners; they receive capital from the senior totse for their trade. These waste collectors are labelled informal operators because they operate outside the purview of state regulation. As we will 


\section{Figure 1: Known operational areas of informal waste collection}

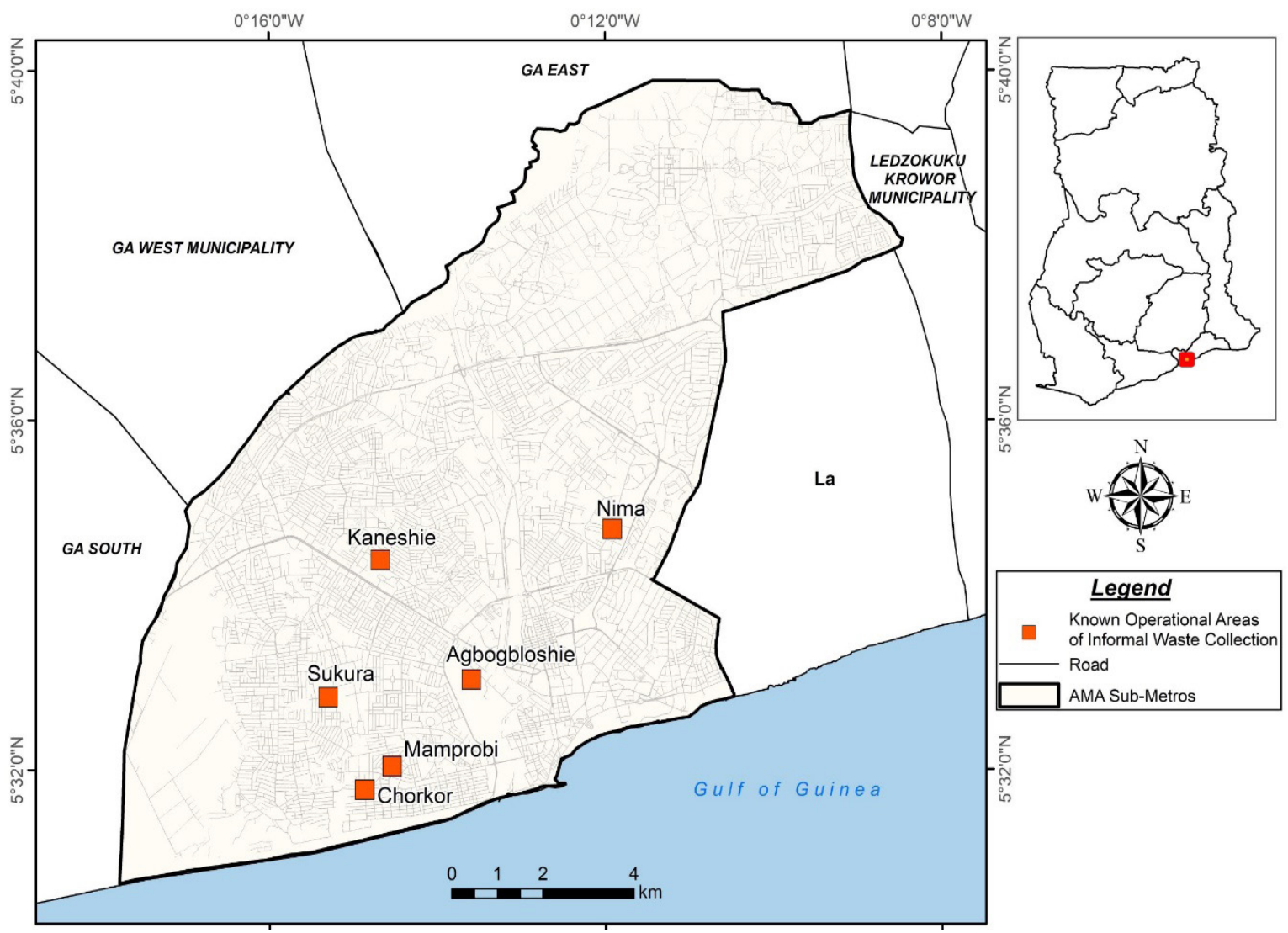

Source: Cartographic Unit of Department of Geography and Regional Planning, University of Cape Coast

discuss in the next section, they are mostly excluded from state-sponsored environmental and sanitation policy, yet they are critical players in municipal solid waste management.

\section{The place of informal operators in Ghana's waste management policy}

The regulatory framework of the waste management sector is the Environmental and Sanitation Policy (2010), which is a revision of the 1999 version. This market-oriented policy inherently neglects the role, and the implications, of increased private participation on informal waste workers (Boampong and Tachie, 2017). A careful look at the policy and its implementation through public-private partnership also reveals a preponderance of attention devoted to formal private contractors to provide waste management services in Ghana. The policy is mostly silent on informal waste operators in the provision of municipal waste management services. The only moment the system came close to recognising informal waste collectors is the stated intention to "develop mechanisms for integrating the activities of 'scavengers' in improved waste collection, transfer and disposal facilities" (p.20). Beyond this, no elaborate steps were espoused in the policy to achieve this policy objective.

The informal waste operators have been evident in resource recovery, reuse, and recycling in Accra, an area often avoided by the formal private operators. There is no structured programme by the municipal authority for informal operators engaged in resource recovery (Oteng-Ababio, 2011b; Gussga, 2012). An official of AMA validated this position when he was asked about the authority's policy for informal operators in robust waste management services, he responded thus: ...the scrap dealers and plastic collectors are not really under our jurisdiction. It is this Ghana Plastic Manufacturers Association which controls them. This association has been able to buy trucks for them and supports them financially. It is just some sort of collaboration, but it does not come under us. We have the representatives of the significant waste contractors and the waste department on the board of directors of the association. So in a way, we are in there to make sure they do the proper thing (Interview with the Chief Environmental Officer, AMA, 09/09/2014).

There is neither a purposeful regulatory regime for informal operators involved in the recovery of recyclable and re-useable materials 
nor those directly engaged in the provision of waste collection services. This observation is consistent with the ambivalent posture of governments in West Africa toward informal waste collectors (Wilson et al. 2006). Again, the operationalisation of private participation through the granting of concessions to formal effectively excludes casual waste collectors or groups of informal waste operators. Our study revealed that all the contractors with legal authority to provide waste management services in the eleven sub-metropolitan assemblies of AMA were largescale private waste contractors. According to the informal waste operators interviewed, the formal contractors and the city officials with the connivance of the police harass and get them arrested should they stray into the concessions of the formal contractors. A case in point is Asadu Royal who reportedly arrested and seized the equipment of Taxi Borla operators who strayed into its operational area of Ablekuma North Sub-Metro. Evidently, informal waste operators in Accra do not only face policy neglect but face occasional harassment from city officials - though not on a broader scale as reported by Medina (1997) in Colombia cities.

\section{Informal operators 'negotiating' for recognition}

As indicated in the literature review section, the experiences of creating the policy space in many developing countries for informal waste operators engaged in waste management are not given. In most cases, the informal operators express agency (individual or collective) to create a policy environment that is supportive of their operations (Samson, 2009; Chikermane, 2012). Regardless of the apparent omission of informal waste operators in public policy by the national and municipal governments, the informal waste operators are subtly negotiating a niche in solid waste management in Accra which gives them relevance and some official recognition. This 'negotiation' we observed is not about political and social activism built on resistance. Somewhat, the informal operators quietly encroach low income and slum areas (Bayat, 2010) to carry out waste collection activities. This is a form of individual agency that is expressed by the informal collectors, and this agency is occasioned by the fact that the informal operators are operationally effective and efficient in the delivery of waste management services in low-income locations than the large-scale formal waste contractors. The compactor trucks often used by formal contractors are unable to access unpaved and narrow streets of slums and low-income communities. The informal operators, however, use small vehicles such as pushcarts, tricycles, and pick-up trucks - transport modes which are suitable for the conditions of low-income areas. The small size and light weight of their vehicles enable informal waste operators to access poor road infrastructure that is characteristic of such communities. An additional operational advantage is the flexible payment terms they offer their clients. They charge daily fees that are priced to meet the income levels of members of the cities. The payment terms make the informal waste operators attractive to the residents of these communities who cannot afford lump sum monthly payments. The Executive Secretary of Environmental Services Providers Association (ESPA) explained that the informal operators are competitive because "they charge low prices. Comparing our prices with the informal waste workers, ours is very bad" (Interview conducted in Accra on 8th September 2014). Medina (1997, pp.23-24) makes a similar observation in Latin American cities where: ...informal collectors using pushcarts, tricycle, donkey carts, horse carts or pick-up trucks serve the poor and retrieve the recyclables contained in the garbage... Given the conditions of hilly, unpaved or narrow streets familiar in those settlements, sanitation trucks may have no access to them.... Thus the vehicles used by the informal collectors are more appropriate to the conditions of the slums and can provide the service at a lower cost than a private company using ... compactor trucks.

It is important to note that critical stakeholders such as the local authority, officials of the formal industry-based association, ESPA and some private waste contractors recognised the operations of the informal operators as necessary in so far as they restricted their activities to localities that the formal operators could not access (See Table 2).

The views expressed by these officials in recognising the complementary role of the informal operators in waste management in Accra seemingly represent a positive change in official attitude. This shift in attitude is consistent with the observation by Medina (1997), Wilson et al., (2006) and Baudouin, et al., (2010) that city officials in many developing countries have come to accept the environmental and economic role of informal waste operators as an essential aspect of municipal waste management. Despite the acceptance of the integral part of informal operators by such vital stakeholders, occasional hostilities toward them remain. Scrap 
Table 2: Acknowledgment of the complementary role of informal operators

\begin{tabular}{l} 
Formal Actors \\
\hline AMA Official
\end{tabular} $\begin{aligned} & \text { Reason for Acknowledging an integral part of informal operators } \\
& \text { bringing them together so that we can license all of them' (Interview with Chief Environmental Officer, AMA, 09/09/2014, } \\
& \text { also see Boampong and Tachie, 2017, p.134) } \\
& \text { "The Taxis Borla operators are normally expected to work in the slums where the contractor cannot reach. For instance, } \\
& \text { when you take a place like Nima, because of the housing arrangements and bad road network, the contractors cannot reach } \\
& \text { all the households hence the need for Taxi Borla" (Interview with the Executive Secretary, ESPA, 08/09/2014) } \\
& \text { "The majority (90\%) of the contractors see the activities of the Taxi Borla as complementary since they help them to clean } \\
& \text { their unreached spaces within their zones" (Interview with the Director of Research, ESPA, 08/09/2014) } \\
& \text { "These waste-pickers play a vital role in SWM because there are some areas that whatever you do the private contractors } \\
& \text { cannot reach..." (Interview with the Director of Research, ESPA, 08/09/2014) }\end{aligned}$

Source: Field data, 2016

dealers reported incidents of arrests and seizure of their trucks and scraps by city officials and the police for allegedly operating on unauthorised routes. They also said that there were occasions when they were wrongly accused of stealing scrap metals. Some Taxi Borla operators reported being accused of colluding with some private contractors to trespass the concessions of others.

The acknowledgment of the existence and critical role of informal waste operators, according to Scheinberg (2001), marks the first step to a supportive official engagement. However, this official recognition is mostly an expressed intention by these formal actors to collaborate with informal waste workers rather than an elaborate policy effort to integrate them into the broader waste management framework. One evidence towards this position is the fact that the acknowledgment of existing complementarity between formal and informal operators in AMA's waste management was conditional. While some advised the need for regulation, as stated below in the words of one contractor; "If they claim to go to areas where our trucks cannot go, then they should register with my company so that they work as our agents" (Interview with the representative of Liberty Waste Services, 09/09/2014), others underscored the need to organise the informal workers, especially the Taxi Borla as a way to regulate their operations. Organising and registration, therefore, became the condition under which the AMA and ESPA could grant informal waste collectors the support to participate as legitimate partners in AMA's solid waste management. The need to register and organise was a significant preoccupation of the informal waste workers, and they were pursuing such efforts. In the next section of this paper, we explore how their motives tied in with those of formal based organs -the public, and the private.
Informal operators organizing for recognition

An emerging development in the waste management sector is the self-organised associations of informal waste workers. Evidence of organising among the informal operators was strong, and the motivating factors for this centred on their operational needs and regulation of their operations. Our study revealed five of such associations in Accra, including attempts to be part of the umbrella body, ESPA. The five associations were the Kaneshie-Amaalataba Association, Ablekuma North Motor Waste Union, Mamprobi Scrap and Plastic Waste Association, Asongtaba Waste Collectors Association, Agbogbloshie Scrap Dealers Association, sub-divided into the Alfa Alhussain/ Korean Boys and Nyankpala Best. Among the informal waste workers, the most organised was Kaneshie-Amaalataba. Characteristically, the members of these associations are migrants from the three northern regions of Ghana. Their executives explained that the issues that engage members at meetings were access to waste management equipment and vehicles, dump site and areas of operation to service waste generators. Some associations regulate entry by registering all motorised tricycle and bicycles used to cart waste in their areas of activity. The scrap dealers had problems with the National Youth Authority (their landlord), which persistently harassed them with ejection. The executives of the Agbogbloshie Scrap Dealers Association lobbied the authority, and upon realising the employment generation potential of the scrapping activity, it regularised their tenancy on the land. It was their connection to the Ministry of Youth and Sports (which has supervisory responsibility over the National Youth Authority) that enabled them to gain access to the land on which to operate. It also facilitated access to a lawyer to assist the association in drafting a 
constitution to meet the requirements for a certificate from the Registrar General's Department. Thus the emergence of self-organised associations in the sector potentially offers the platform for recognition and legitimization to facilitate state support either directly or indirectly. Scheinberg (2001) explains that such support might entail direct public and private support to stimulate the activities of informal operators or through some contracting with them to gain access to points of collection. Generally, the evidence of purposeful national and local government's support for these associations to enable them to address their operational challenges is very limited. The rare exception, as indicated earlier, is the more significant Accra Scrap Dealers Association which was able to gain access to land through their formalised relations with the state ministry responsible for youth. The vice-chairperson explained:

The rationale for the formation of the association is the land we work on... it belongs to the National Youth Authority. We had challenges... till they asked us to form an association if we wish to work on the land. The authority explained that they deal with the youth of Ghana and ... our activities employ the child (Interview with Vice Chairman of Agbogbloshie Scrap Dealers Association, 10/09/2014)

\section{The enabling role of other stakeholders}

There is evidence across many developing countries where other stakeholders such as NGOs and Trades Unions helped to promote the formalization of informal waste operations in municipal solid waste management. For example, the trade union, Kagad Kach Patra Kashtakari Panchayat (KKPKP) in India, was instrumental in establishing $\mathrm{SWaCH}$ (a cooperative of informal waste operators) and subsequently advocating for its integration into the municipal solid waste management in the city of Pune (Chikarmane, 2012). The Coptic Church in Egypt also helped to establish the Zabbaleen, an association of Coptic Christians who are waste collectors and recyclers in Cairo. The association received essential infrastructure support and financial assistance from organizations such as the Ford Foundation, World Bank, and Oxfam (Wilson et al., 2006; Medina, 1997). The evidence of non-governmental organizations advocating for existing informal-based waste associations for policy recognition and other forms of support in our study is non-existent. Likewise, the presence of unions organizing and advocating for informal waste operators was absent. The reason for this situation is not very clear. However, unions' effort at organizing informal waste operators, in general, is weak in the sector, partly on account of the attitude of union leaders in organising waste workers. The leader of the main union in the industry, the Local Government Workers Union, indicated that the low incomes of workers in the sector did not merit the investment in their unionisation. The union considered the gains from waste worker members' subscriptions unattractive.

ESPA is filling the organizational vacuum left by NGOs and trade unions; the sector-based organisation whose membership was predominantly large-scale private waste contractors. The association was willing to work with organised informal operators, as evident in the quotation below. There is talk about the capacity of the informal waste operators to engage in meaningful dialogue and perform responsibly when trained. The ESPA officials claim that the motive for reaching out to the informal waste workers is to train and educate them on occupational health and safety issues, cater for their welfare needs and to help address their operational challenges. An ESPA official had this to say:

The reason for organising informal waste pickers is to train and educate them in the areas such as wearing protective gears in the course of their operations ... The main challenge with the Taxi Borla operation is that they dump indiscriminately, so bringing them under our umbrella will help us to regulate their activities. ESPA also wish to educate them to prevent the harm they are causing to the environment and the nation. Also, joining ESPA will make them a recognised body in the waste management industry, and as such, they can make more money. The mission of the current president is to support them (Taxi Borla) with equipment (Interview with the Executive Secretary, ESPA, 08/09/2014)

But perhaps it is the motive that explains this willingness to organise them. It appears the purpose of ESPA for reaching out to informal waste operators is to seek to control their activities because they are deemed aggressive and to lack discipline. Some of the members of ESPA have discomfort for dealing with the informal operators, especially, the Taxi Borla operators, because of their potential to displace the contractors. A private waste contractor had this to say to reinforce this position:

The 'Borla kings' at one point are competing with us ... Why am I saying this? They want to take 
over our work but sometimes where our trucks cannot go to pick the waste they go there to collect them for us, and they take that as an advantage even though they are helping to make the city clean (Interview with a Representative of Platinum Waste Management Ltd, 11/09/2014).

\section{Conclusion and Policy Implications}

This paper reveals that formal waste contractors who have partnership arrangements with the municipal authority in Accra, AMA, tend to concentrate their services in high-class residential areas in their concessions, leaving large parts of low-class areas underserved. The informal waste collectors fill this gap by providing services to these underserved communities though they do not have the right over the source of waste generation. The formal waste contractors and the municipal authority have come to accept this gap-filling role of informal waste operators as a valuable waste management service. This notwithstanding, informal waste operators do not have the official recognition as actors who can legitimately enter into a public, private arrangement with the government. The informal waste operators in Accra neither face pronounced hostilities, nor are they officially recognised as part of the broader waste management framework. The recognition granted to informal waste collectors remains informal, not codified. The opportunities for informal waste operators to be given formal recognition are enormous, and they stand to benefit both the municipal authority and residents in the metropolis. The acceptance of the gap-filling role of informal operators in waste management services creates a situation that can bolster their efforts to create employment in the country. Public-private partnership in waste management in countries such as Ghana can operationally and spatially be effective if informal operators are granted the needed recognition and support to operate as legitimate partners of local governments and formal private entities.

\section{References}

Adama, O. and Nzeadibe, T.C. (2013).

Improved recycling performance:

Policy Options for Nigerian Cities.

Policy Note, 2. The Nordic African

Institute

Baudouin, A., Bjerkli, C., Habtemaraim, Y., and

Chekole Z.F. (2010) Between Neglect
There are potential entry points for structuring the relations between the municipal authority and the informal operators to facilitate their compelling and legitimate operations in waste management in Ghana's capital city Accra. The change in attitudes of AMA and private waste contractors is a positive and first important step toward formal policy recognition of informal operators. The existing self-organised associations of informal waste operators though at the embryonic stage of their development can provide the platform for collective engagement with the local authority and other stakeholders for policy space. These selforganised associations, however, lack the gravitas and voice necessary to influence waste management policies. Global experience shows that where the associations of informal waste workers have made any meaningful impact in changing their adversarial environment, they did so by establishing a strategic alliance with NGOs and donor agencies. These selforganised associations of informal waste collectors in Accra will require organisational and technical support, preferably from NGOs to effectively engage policy actors for the representation of their interests in the waste management policy process.

By creating a waste management niche in low income and slum areas and the fact that this function is considered by many as complementary to the role of formal private waste contractors, it can become the basis for partnership arrangements between the formal waste contractors and informal operators. The self-organised associations that have emerged will make it easier for formal waste contractors and AMA to deal with a collective pool of informal waste operators than individual informal operators. This has the potential of enabling a large pool of young people surviving at the margins of the city economy to attain some of the sources of employment and at the same time offer valuable waste management service to the city.

and Control: Questioning Partnerships and the Integration of Informal Actors in Public Solid Waste Management in Addis Ababa, Ethiopia. African Studies Quarterly, 11(2and3), 29-42. Bayat, A. (2010) Life as Politics: How Ordinary People Change the Middle East. Amsterdam. Amsterdam University 
Press.

Boampong, O., and Tachie, B. Y. (2017). Implications of Private Participation in Solid Waste Management for working conditions and collective organization in Accra. In E. Webster, A. O. Britwum and S. Bhowmik, (Eds.). Crossing the Divide: Precarious work and the future of labour (pp.121142). KwaZulu-Natal, South Africa: University of KwaZulu-Natal Press.

Chikarmane, P. (2012) Integrating Waste Pickers into Municipal Solid Waste Management in Pune, India. Policy Brief, 8. WIEGO

Contreau-Levine, S. (1995). Private Sector Participation in Municipal Solid Waste Services in Developing Countries, Vol. 1, The Formal Sector. Urban Management Programme by the World Bank, Washington, D.C.

Gadgil, M. and Sampson, M (2017). Hybrid Organisations, Complex Politics: When Unions form cooperatives. In E. Webster, A. O. Britwum and S. Bhowmik, (Eds.). Crossing the Divide: Precarious work and the future of labour (pp.143-164).KwaZuluNatal, South Africa: University of KwaZulu-Natal Press.

Gerdes, P. and Gunsilius, E. (2010). The waste experts, the enabling conditions for informal sector Integration in Solid Waste Management: Lessons from Brazil, Egypt and India. Germany: Deutsche Gesellschaft für Techische Zusammenarbeit (GTZ) GmbH.

Gugssa, B. T. (2012).The Cycle of Solid Waste: A Case Study on the Informal Plastic and Metal Recovery System in Accra. Unpublished Master thesis, Department of Earth Sciences Uppsala University, Sweden.
Gupta, S.K. (2012) Integrating the Informal Sector for Improved Waste Management. Proparco's Magazine (Private Sector and Development), Issue No.15, pp.12-15.

Kassim, S.M., and Ali, M. (2006) 'Solid waste collection by the Private Sector: Households' Perspective-Findings from a study in Dar es Salam city, Tanzania', Habitat International, 30:769-780.

Katusiimeh, M.W., Mol, A. P. J., and Burger, C.P.J (2012). The operations and effectiveness of public and private provision of solid waste collection services in Kampala. Habitat International, 36, 247-52.

Medina, M. (1997). Informal recycling and collection of solid waste in developing countries: Issues and Opportunities. United Nations University/Institute of Advanced Studies working paper, No. 24.

Oteng-Ababio, M. (2010). Private Sector Participation in solid waste management in the Greater Accra Metropolitan Area in Ghana. Waste Management and Research, 28, 322329.

Oteng-Ababio, M. (2011a). The role of the informal sector in solid waste management in the GAMA, Ghana: Challenges and Opportunities. Tijdschrift voor Economische en Sociale Geografie, 103(4), 412-425.

Oteng-Ababio, M. (2011b) Missing links in Solid waste management in Greater Accra Metropolitan Area in Ghana. GeoJournal, 76, 551-560.

Samson, M. (2009) Confronting and Engaging Privatization. In Refusing to be Cast Aside: Waste Pickers Organizing around the World. Cambridge, M.A: 
WIEGO.

Scheinberg, A (2001) Micro and Small Enterprises in Integrated Sustainable Waste Management: tools for Decision-makers, experiences from the Urban Waste Expertise programme?

Van de Klundert, A. and I. Lardinois (1995) Community and Private (Formal and Informal) Sector Involvement in Municipal Solid Waste Management in Developing Countries. Background paper for the UMP workshop in Ittingen, 10-12 April.
Wilson, D. C., Velis, C. and Cheeseman, C. (2006) Role of Informal Sector Recycling in Waste Management in Developing Countries. Habitat International, 30, 797-808. 